\title{
THE CULTURAL MEANING OF A. GLAZUNOV'S CONCERTOS FOR PIANO (dedicated to the memory of my Teacher, professor Yuri Nekrasov)
}

Androsova D. V.

\section{INTRODUCTION}

The work of A. Glazunov is a basic phenomenon of twentieth-century art and modernity, since the composer linked the achievements of the art of Russia, Ukraine, and Western Europe with the events of his creative biography. The publication of a book about A. Glazunov ${ }^{1}$ in Germany in the 1980s, testifies to a new wave of interest in his work, which represented the style of "academical" modernism in the early twentieth century. A. Glazunov's concertos for piano have undoubted artistic merits, adorning the repertoire of European pianists, but due to historical circumstances are little known in Ukraine and neighboring countries. The literature on Glazunov is quite extensive, including lifetime editions of materials about the work of the composer ${ }^{2}$, and including the work of A. Ossovsky ${ }^{3}$, a professor of the Odessa Conservatory, which was written in 1917-1921 as well as monographic expositions of Glazunov's life and work in 1940s - 1960s which include books by M. Ganina ${ }^{4}$ and A. Kryukov", encouraged by a great admirer of A.K. Glazunov - S.D. Orfeev. The thesis of professor Markova was written on this subject as well. There was some pause in the publications, due to the switching attention of musicological researches to coverage of the issue of the modernism and avant-garde style in the composers' works, which was not customary to talk about in Russian literature until the 1970s. In this sense, the monograph of 1998 by D. Goyovi, an outstanding German musicologist who has repeatedly come to Ukraine to conferences and creative meetings, is symptomatic. The work of Goyovi, firstly, removed the taboo from the description of the overseas period of Glazunov's activity, and, secondly, demonstrated the "insignificance" of the great composer's work in (according to E. Markova's ${ }^{6}$ research the environment of "neo symbolists" 7 .

${ }^{1}$ Gojowy D. (1986). Alexander Glasunow. Sein Leben in Bildern und Dokumenten. Unter Einbezihung des biographischen Fragments von Glasunows Schwierigersohn Herbert Günter. München: Paul List Verlag GmbH \& Co.KG.

${ }^{2}$ Glebov I. (B.Asafiev). (1924). A.Glazunow. Opyt harakteristiki. Leningrad.

${ }^{3}$ Ossovskiy A.(1907) A.K. Glazunow. Jego zhizn I tvorchestvo. S.-Peterburg.

${ }^{4}$ Ganina M. (1961) A.K. Glazunow Zhizn I tvorchestvo. Leningrad.

${ }^{5}$ Kryukov A. (1966) Alexandr Konstantinobich Glazunow. Moscow, Muzyka.

${ }^{6}$ Markova E. (1968) Preludii I fugi A. Glasunova dla klavira. Dipl.rab. Bibl, ONMA imeni A.B. Nezhdanovoj. Odessa.

${ }^{7}$ Markova E. (2012) Problemy muzykalnoy kulturologii. Odessa: Astroprint, P. 99-134. 
This study identifies the cultural foundations of symbolism in defining the stylistic and ideological features of the composer's traditionalist heritage and the particular importance of piano concertos in it, which corresponded to the performances of the early XXIst century.

\section{1. "Mozartian complex" of Glazunov as composer and pianist}

The German musicologist D. Goyovi began his monograph “Alexander Glazunov" with significant words: "In the memory of his contemporaries, he remained the last classic of Russian music" ${ }^{8}$. It was about the classics of the Mighty Handful and the New Russian School. The composer turned out to be the heir to their style. He was a younger contemporary of K. Debussy and a few years older than A. Scriabin, he belonged to a generation of "triumphant modernism", where the work of I. Stravinsky became the culmination of a national and global scale. True, German musicology in the person of the great historian G. Adler approved precisely of the composers of the Mighty Handful, belonging to the New Russian School, and the beginning of European modernism style from the $1870 \mathrm{~s}^{9}$. However, within the national Russian tradition, the group of composers formed around M. Balakirev, among whose participants the genius of M. Mussorgsky, A. Borodin, N. Rimsky-Korsakov was formed, and was recognized as the "generation of the sixties", (the 1860s,) whereas the modernism schools of Moscow and St. Petersburg dates from the 1890s - 1900s. Traditional, by Russian standards, Glazunov's orientation, was defined by D. Goyovi as "an early discovery of the composing talent" and not without reason - one of the chapters on the Glazunov eenager is called "Gymnasium student and composer," and from the age of fifteen the great Rimsky-Korsakov called his student Glazunov his friend ${ }^{10}$.

In Russian publications, this "Mozartian complex of talent" for various reasons is not customary to emphasize. A. Kryukov (see above) indicated the exceptional importance of the composer's First Symphony, written in 1881-1882 years (when the author was barely 17 years old) both in Glazunov's personal biography and in the history of Russian music. At the same time, the young master completely and organically accepted the style of the composers of the "Mighty Handful", but found a quality that was extremely reserved for the generation of M. Mussorgsky, reaching for "truth

${ }^{8}$ Gojowy D. (1986). Alexander Glasunow. Sein Leben in Bildern und Dokumenten. Unter Einbezihung des biographischen Fragments von Glasunows Schwierigersohn Herbert Günter. München: Paul List Verlag GmbH \& Co.KG. P. 7.

${ }_{9}^{9}$ Adler G. (1924) Handbuch der Musikgeschichte. Frankfurt a.M.: Verlag-Anstalt. P. 901.

${ }^{10}$ Gojowy D. (1986). Alexander Glasunow. Sein Leben in Bildern und Dokumenten. Unter Einbezihung des biographischen Fragments von Glasunows Schwierigersohn Herbert Günter. München: Paul List Verlag GmbH \& Co.KG. P. 7; 17; 22. 
recitative": lyricism of talent. The lyrical line was more associated with the Moscow school, and with P. Tchaikovsky, who inherited the beauty of the Russian Moscow romance in the waltz style, which was proprietary for the works of A. Varlamov - A. Gurilev.

In the style of Russian art, the period that anticipated symbolism in the early 1880s, organically renewed European musical thinking in the direction of lyrical monologue, the classics of which were noted by Beethoven's tough symphonic dialogical nature. An important role in such a stylistic "restructuring" for musical Europe was played by the appeal to the experience of the art of the East and to China in particular, in which it was the lyrical side of music that became the fundamental basis of its artistic significance. In listing the most significant works of the early 1880s, that are, works created before Glazunov reached his 20th birthday, we find, on the one hand, dramatic-picture compositions in style and ideas close to style of the "The Mighty Handful" composers ("Characteristic Suite" in the spirit of "songs-sketches" by Mussorgsky, Overture on Greek Themes, ${ }^{11}$ symphonic poem «Stenka Razin» et al.), and on the other hand - "Lyric poem", elegy for orchestra «To the Memory of a Hero», etc.

The natural expression of the line of Glazunov's lyrical style, adopted from the composers of "The Mighty Handful» was the friendship with P. Tchaikovsky, who, on the whole, disliked M. Mussorgsky. The composers of the «Mighty Handful» avoided turning from the monumental folk style and preferred style of "lyrical scenes" of the opera "Eugene Onegin" and others. A summary of these contacts is recorded in the composer's memoirs: "Subsequently, I got closer to Pyotr Ilyich (Tchaikovsky - F.S.), and finally we made a close friendship, that continued growing to his death ..."12.

Of course, this was not about the fact of "misunderstanding" the individualities of the schools of St. Petersburg and Moscow, but about the significance of differences in the ideas of the future of Russian music. Similar problems were faced before generations of the "sixties" in Germany though at the Leipzig and Weimar schools, the severity of the confrontation began to disappear by the 1890s after the death of R. Wagner (P. Tchaikovsky category-cally did not accept his music). The direct influence of P. Tchaikovsky marks the Third Symphony, which in this connection is considered "the most unsuccessful” 13 .

This description of "Tchaikovsky's influence" sounds rather derogatory - the academic style of "The Mighty Handful" contributed to the

\footnotetext{
${ }^{11}$ Kryukov A. (1966) Alexandr Konstantinovich Glazunow. Moscow, Muzyka. P. 18.

12 Ibid. P. 26.

${ }^{13}$ Ibid. P. 42.
} 
development of such an attitude to the "lyrical exits" of Glazunov among Russian Leningrad musicians of the USSR era. Tchaikovsky himself praised Glazunov's Third Symphony.

In turn, as the studies of D. Goyovi show, Glazunov with extraordinary enthusiasm received the "Iolanthe" P. Tchaikovsky ${ }^{14}$. The appeal to the poetry of French chivalry was continued by Glazunov - in one of the best works of this author - in Raymonda's ballet (1895-1898). It is interesting to note, the lyricalpsychological genre of ballet and the appeal to this genre, which was generally ignored by the composers of «The Mighty Handful», which is a sign of Tchaikovsky's influence.

The highest point of A. Glazunov's symphonia - his Fourth, Fifth and Sixth symphonies - is marked by an amazing synthesis of the monumentality of the style of the composers of the "Mighty Handful" and the completeness of the lyrical detection of melodicism. Moreover, melodicism, in the spirit of the time of anti-romantic intellectualism of the late 19th century, organically merged with polyphonic mastery: the great polyphonist and student of P. Tchaikovsky, S. Taneev, also turned out to be "introduced" into the stylistic laboratory of the author of three remarkable Symphonies. The above monograph by D. Goyovi directly states that S. Taneyev and G. Larosh, who were representatives of the Moscow school and were part of Tchaikovsky's social circle (to whom N. Rimsky-Korsakov was "hostile"), enjoyed the friendly participation of A. Glazunov ${ }^{15}$.

The indicated feature of Glazunov's lyricism, namely in connection with the expressive intellectual "estrangement", constituted an extremely revealing feature of the thinking of the artistic circles of composers who were in favour of symbolism, in particular, in favour of the emotionally "cool" lyrics of C. Debussy.

In the work of Liu Bintsyan, special attention is paid to the influence of China on the cultural principles of twentieth-century Europe, which had total meaning, independent of the special inclinations of Chinese Doctrines or their lack in the work of one or another author:

"The beginning of the twentieth century was marked by the dramatic events of the Russo-Japanese War.... Forgotten pages of history about China as an ally of Russia (in the materials published in Odessa by the Russian Musical Bulletin for 1915) were collected and report about classical Chinese art and cultural discoveries of China, such as the invention of paper, were

${ }^{14}$ Gojowy D. (1986). Alexander Glasunow. Sein Leben in Bildern und Dokumenten. Unter Einbezihung des biographischen Fragments von Glasunows Schwierigersohn Herbert Günter. München: Paul List Verlag GmbH \& Co.KG. P. 55.

${ }^{15}$ Ibid. P. 58. 
popularized with great interest and respect. It become the property of the world cultural space” ${ }^{\#}$.

Given the special trust of A. Glazunov to the work of P. Tchaikovsky, and, consequently, to pro-symbolism and pro modernism ideas, the author of «Stenka Razin» turned to the ideals and discoveries of the era of symbolism and modernism as a whole.

Lyricism became the center of preferences for pianistic modernism represented by G. Gould, who was the focus of the specifics of musical thinking and pianism of the twentieth century, which is recorded in the relevant materials in the author's book based on the materials of J. Peisan: "His (G. Gulda - D.A.) piano style - subtle, sophisticated, rhythmically dynamic (hereinafter D.A. italics), structurally defined, strongly counter-punctual - was more modern than romantic, but still remains more lyrical and deeply expressive" ${ }^{\text {"17 }}$.

The modern world of Ukraine is marked by signs of post-post-modern art, the meaning of which became the subject of research in the dissertation of I. Navoeva, where this meaning is formulated as a neo-Gothic in the musical refraction of creative practice ${ }^{18}$.

The presented argumentation of the historical order is supplemented by generalizations from the sphere of performing art of the last decades indicated by the author - a capacious generalization is created in which the musicaltraditionalist stream takes a special and honorable place. In this context, the reaction to the work of A. Glazunov is extremely increased, prompting attention to the indicated artistic phenomenon in the traditionalist sphere of creativity of the twentieth century.

A. Glazunov began as a composer-pianist, and a significant part of his compositions is intended specifically for this instrument. According to D. Shostakovich, he "played well" on the piano, however, it is noted that "Glazunov had no technique by today's standards". But he played deftly and artistically, including - ... with a cigar sandwiched between the third and fourth fingers; played "everything, including the hardest passages." He masterfully played the scores, as they say, "from the sheet". As a conclusion, Shostakovich formulated the following: there was a certain "secret" in his game, a secret that takes out the performer "on the wave of success" 19 .

${ }^{16}$ Liu Bing Jang (2014) Muzykalno-istoricheskiye paralleli razvitiya iskusstva Kitaya i Evropy. Monografiya po istorii kultury dla muzykalnyh akademiy, universitetov I vuzov iskusstva. Odessa: Astroprint, P. 255.

${ }^{17}$ Androsova D.V. (2014) Symbolism i poliklabirnost v fortepiannom ispolnitelstbye XX v. Monografiya. - Odessa: Astroprint. P. 34.

${ }^{18}$ Navoeva I.Л. (2018) Ukrayinska horova, vokalno-ansambleva tvorchist u konteksti stylovoyi neogotyky post-postmodernu. Kandydatska dysertaciya, OHMA, 17.00.03. Odesa. P. 89-90.

${ }^{19}$ Gojowy D. (1986). Alexander Glasunow. Sein Leben in Bildern und Dokumenten. Unter Einbezihung des biographischen Fragments von Glasunows Schwierigersohn Herbert Günter. München: Paul List Verlag GmbH \& Co.KG. P. 116. 
In the process of developing of Glazunov composer's talent, symphonic and orchestral compositions began to prevail in his work. Among the later works are polyphonic forms intended for the clavier organ (see the work of E. Markova ${ }^{20}$ ). In this regard, the appearance of the First, f-moll (1911) and Second H-dur (1917) piano concerts is logical: there is a "coalescence" of clavier-piano and orchestra compositions.

The key of the first concert of f-moll is one of the composer's favorite songs: it is one of extremely popular Beethoven's tonalities, along with D-dur (Third Symphony), d-moll (Ninth Symphony), F-dur, G-dur / g-moll, Es-dur (Fourth, Eighth Symphonies, The Concerto for alto saxophone and string orchestra, c-moll (Sixth Symphony) in the works of Glazunov. "Romantic", "golden" tonality of Des-dur, beloved by Franz Liszt (watch the iconic romantic genres: Nocturne op. 37, Dreams, op. 24, Two Impromptus for clavier opus 54, etc.) is also significant - here, and in further materials of the works of Glazunov - according to the catalog of Goyovi ${ }^{21}$.

Among these works of Glazunov, a significant place belongs to concert genres. For him, the genre of a concerto-ballet such as "Cohenian", Concert Waltzes Op 41 Es-dur and Op. 47 D-dur, Concerto ballad for cello and orchestra op. 108, dedicated to P. Casals et al., The Coronation Cantata op. 56, 1896, Festive cantatas for the 100th anniversary of the Pavlov Institute op. 63 and to the 100th anniversary of the birth of A. Pushkin, op. 65, Anthems of Pushkin, op. 66, Festive overture for orchestra op. Op. 73 and others.

The above is a characteristic of A. Lunacharsky's works of Glazunov's compositions, in which the joyfully playful nature of his images was emphasized, which is quite far from the revealing tragedy of the works of M. Mussorgsky, and from the lyrical-dramatic pathos of the works of P. Tchaikovsky. But it is comparable with "The Island of Joy" by K. Debussy, with the elegant catchiness of the works of I. Stravinsky and M. Ravel.

Notably, it is precisely the concerto compositions of P. Tchaikovsky that stand out in the style of joy among his symphonic and opera compositions ${ }^{22}$. The community of the concept of the cycle, which differs from the Fourth Symphony, is noted: the gala character in the first parts of the Concertos and the "lyrical-dramatic" in the Symphony.

The conclusion is drawn about the special kind of influence of the concerto genres of $\mathrm{P}$. Tchaikovsky on concerto compositions and, more broadly, Glazunov's symphonic works.

${ }^{20}$ Markova E. (1968) Preludii I fugi A. Glasunova dla klavira. Dipl.rab. Bibl, ONMA imeni A.B. Nezhdanovoj. Odessa.

${ }^{21}$ Gojowy D. (1986). Alexander Glasunow. Sein Leben in Bildern und Dokumenten. Unter Einbezihung des biographischen Fragments von Glasunows Schwierigersohn Herbert Günter. München: Paul List Verlag GmbH \& Co.KG. P. Gojowy D. A. P. 155-158.

${ }^{22}$ Alshvang A. (1967) P.I. Chajkovskiy. Moskwa: Muzyka. P. 271. 
The statement by B. Asafiev regarding works written in the 1890s, which are most influenced by the dramatic searches of the composers of «The Mighty Handful» and P. Tchaikovsky, to which A. Kryukov refers and supplements with his own generalization, is indicative: “... in the mid-1990s, in Glazunov's symphonies only occasionally can episodes of condensed and gloomy color be seen, only as an exception (here and before, italics by D.A.) dramatically saturated pages appear ....23.

The concerto as a genre in the heritage of Glazunov reflected one of the most important typologies of his creative manifestations. On this occasion, he wrote about himself in the 1920s, after leaving Soviet Russia: “As in «Poltava» is said about Kochubey, I also had three treasures - creativity (meaning composition classes - D.A.), communication with my favorite institution (organizational activities of the director of the Leningrad Conservatory - D.A.) and concert performances (italics $-D . A$.). "Something does not go well with the first one ...

I have cooled off on such (organizational and directorial - D.A.) work." It remains only to "ride with concerts" ${ }^{24}$.

Concert activity, as a way of making a musical statement about oneself, is the finale decade of the great composer. D. Goyovi, a researcher of the work of Glazunov in the 1980s, summarizes this play aimed at confirming the authority of Russian music, and the composer's activity refers to his stylistic credo: "Glazunov was a classicist by instinct and not by ideological programme" ${ }^{25}$.

Of course, the music writer had in mind "artistic instinct", the phenomenon of which is indicated by the lines of one of the composer's last letters, which is surprisingly accurate in characterizing civic and creativepersonal positions:

"I have always loved my musical creativity. The desire for "new shores" ... did not appeal to me, because even in my youth I did not act as an innovator; but also, I was not a routine. I've always composed with inspiration ... "26.

As you can see, lyricism, as a manifestation of love and the inspiration of labor, permeates the entire creative path of the composer. He was called to glorify the music of his homeland by happy life circumstances and benevolently approving attitude of contemporaries.

The work of A. Glazunov is an emblematic phenomenon of Slavic culture at the turn of the nineteenth and twentieth centuries in line with the emerging traditionalist meta-direction of the century of the Scientific and

${ }^{23}$ Kryukov A. (1966) Alexandr Konstantinovich Glazunow. Moskva, Muzyka. P. 56.

${ }^{24}$ Glazunov. Issledovanija. Materialy. Publikacii. Pisma. T. 1-2, 1959, 1960. T. 1. P. 104-105.

${ }^{25}$ Gojowy D. (1986). Alexander Glasunow. Sein Leben in Bildern und Dokumenten. Unter Einbezihung des biographischen Fragments von Glasunows Schwierigersohn Herbert Günter. München: Paul List Verlag GmbH \& Co.KG. P. Gojowy D. A. P. 152.

${ }^{26}$ Ibid. P. 152-153. 
Technical Revolution. Gathering the possibilities of the artistic and selfsufficient sphere of music at the turn of the epoch had an outlet for a special kind of combination of stylistic antitheses in different countries, which arose within the framework of national composer and performing schools. A. Glazunov symbolized the "coalescence" of St. Petersburg and Moscow schools in a stylistic symbiosis of personal lyricism, which combined the flows of collective images of the composers of the "Mighty Handful" and individualized lyricism of P. Tchaikovsky, as well as his direct projections into the works of A. Skryabin, S. Taneyev, S. Rachmaninov and others. Glazunov marked the inheritance of historical and epic images of M. Mussorgsky - A. Borodin, but at the same time he tenderly emphasized the music of P. Tchaikovsky, the connections with which appear in his genre preferences of instrumentalism and ballet. Piano compositions did not occupy the main place in the composer's legacy, despite the fact that he was inherent in the possession of the instrument, moreover, in a clear (coquettish and demonstrative) manifestation of the connection with the salon style of playing. The reference to monumental piano forms, of which certain poles made up the polyphonic Fugues for clavier (piano or organ) and piano concerts, is indicative.

\section{Concertos for piano and orchestra A. Glazunov №№ 1, 2 in modern performing reading}

The composer's piano concertos at the time of their writing $(1911,1917)$ form something "median" between the classics of the Glazunov period, who wrote after the completion of the composing activity of «The Mighty Handful», and the extremes of the Soviet-foreign period of the 1920s. Both works appeared at stylistical turning points regarding historical events and artistic aspirations of musicians. 1911 is the Chinese Revolution, 1917 is the Great October Revolution in Russia, the victory of the Mexican Revolution (1910-1920), which contrasted Latin America with the power of the rising military and political giant - US. Also, 1911 year is the year of the appearance of "Petrushka" by I. Stravinsky, "Lunar Pierrot" by A. Schoenberg, "Allegro barbaro" and "Castle of the Duke Bluebeard" by B. Bartok.

1917 year was marked by the rise of the French Six (as a community, the Six composers acted from 1917 to 1923), the approval of the classics of "hot jazz" (1917-1923), and I. Stravinsky's turn from Fauvism of the "Russian" period to neoclassicism (creating of "Weddings" in three editions - 1917-1923). The historical context makes both the Glazunov Piano Concertos, that capture the extremely important style trends of the time and the perspectives of culture. The first concerto is dedicated to L. Godowsky, a wonderful conductor who, with his work, proved the exaltation of professional traditions. In 1911, 
the aforementioned musicians were shocked by a furious statement, in the persons of I. Stravinsky, A. Schoenberg, B. Bartok, and others, the "new shores" of the consistent anti-traditionalism of the modernism-avant-garde.

The traditions of romantic academicism determine the stylistic appearance of the f-moll First Piano Concerto, capturing the symbolism of Beethoven's Appassionata and Tchaikovsky's Fourth Symphony in the dimensions of the lyricism of the beauty of these traditions. Do not forget that this Concerto was composed in the year when the Cantata was prepared for the celebration of the 50th anniversary of the St. Petersburg Conservatory, where M. Stravinsky, a student of the master of this great educational institution of all-Slavic and world significance, performed. Glazunov's position in this cultural context is uniquely defined: to maintain and to development of traditions as a basis for cultural construction as a whole.

The tonality of the Second Piano Concerto - H-dur - is quite distant from the tonality's preferences accepted in Glazunov's work (see above). Its romantic symbolism is obvious - the tonalities of enthusiastic lyrical revelations of romantics opposing the "black Nothing" h-moll. Note, in the legacy of Glazunov himself, h-moll is found almost once - in one of his closest compositions to the works of composers of "Mighty Handful” in poem "Stenka Razin” (1885).

This interpretation of the symbolism of the h-moll tonality is indirectly confirmed by the emblemism of H-dur in the Second Piano Concerto, dedicated to Nicholas II, which embodied the monarchical tradition, which once was severely tested in the epic of uprising of S. Razin. The specter of a new Civil War was obviously revived by the Russian Revolution in 1917 and Glazunov ambiguously defined his attitude to it: stabilization and preservation of the traditions of Russian statehood.

The Second Piano Concerto is a one-part concerto-poem (one more structural and genre moment of correlation by the antithesis of the poem "Stenka Razin" and the Concerto). Moreover, the Concerto code sets the E-dur tonality, which is not the main one, and in the last three measures of the composition, a stylistic quote is written from A. Borodin's Heroic symphony. Only the h-moll of the "heroic robbery" $\mathrm{cry}^{27}$ is not chromatized, a diatonically built melodic turn the composes a unified sound, like Borodin's, the rhetorical figure of the "ring" (see the beginning and the end of the motive-theme on the same sound) - the theme of the end of the concerto of A. Glazunov and the theme of cry of heroes by A. Borodin.

In the rhetorical symbolism of ancient music and antiquity, the theme of the "ring-circle" captures God. Only Borodin's unison is "immersed" in a sequence of tertz descents, vaguely reminiscent of dies irae, in which pitch

\footnotetext{
${ }^{27}$ Markova E. (1990) Intonationnost muzykalnogo iskusstva. Kiev: Muzychna Ykrajina. P. 174.
} 
of $e$ is only "affected". In the Glazunov Concerto, the support of $\mathrm{E}$ is demonstrative (like g / G tonality at the beginning of the Liszt Sonata h-moll ...). E-dur is the quality of meaning, which in romantic music is presented as the "tonality of an ideal state".

The Second Piano Concerto by A. Glazunov is marked with the jubilee opus 100 for the composer, continuing the jubilee dedications of op. 63-65 (see above), dedicated to the 100th anniversary of the Pavlovsk Institute, the 100th anniversary of the birth of A. Pushkin in 1898 and 1899. In the year of the writing of the First Piano Concerto, the Prelude Cantata was created for the $50^{\text {th }}$ anniversary of the St. Petersburg Conservatory.

The considered Piano Concerto No. 2 is built in poetic form and in tonal relationships, symbolizing the new tonal system of music of the late 19th early 20th centuries: this is the same-parallel-single-third relationship as "a complex modal - harmony-pitch relationship of tonalities".

It is indicative that op. 101 Glazunov - "Four Preludes and Fugues a-moll, cis-moll, c-moll, C-dur”, in which the idea of the identity of the same name of parallel and single third relationships is "naked".

The poem structure of the Second Concerto has something different from the poetic classics of F. Liszt: two-phases, the presence of double exposure in abnormal tonal parallels $\mathrm{H}-\mathrm{F}$. Here, a comparison with the Symphony of d-moll S. Frank, in which the double exposure of d-moll - f- moll. Thus, the H-dur - F-dur relationship in the Glazunov Concerto is perceived as an integral sphere of the tonic, and its components $\mathrm{H}-\mathrm{F}$ both are carriers of the tonalexposure function. Tonalities of F-dur and E-dur act as single third of the same name (F-dur is self-titled to f-moll, and E-dur forms a one third construction to f-moll), which creates the effect of tonal reprise in the second phase of the Concerto: H-dur and E-dur are analogous to the relationship of H-dur and F-dur in the initial double exposure.

The polyphonic principle of thinking of A. Glazunov in the Bach style is found in the strategy of gradual rhythmic fragmentation from the beginning to the end of the composition. The sixteenth movement on the first pages of the work is done at the pace of Andante, while the appearance of Allegro is marked by the ratio of the lengths of eighths and quarters. The final stage of the composition is marked by game fragmentation of movement by sixteenths in quarters and sextuples.

Both the first and second themes of the Concerto form a single semantic complex of the lyrical anthem. The first topic is based on the sequence of anabasis, that is an ascending line that signifies in moderate movement the symbolism of aspiration from the earth to Heaven. The sound of the theme in the timbre of low male voices is indicative, which creates associations with the strict style of choral singing, correlated with the church. However, the emphasized 
rhythm of the polonaise, associated with the official anthem of the post of Napoleonic Russia, creates a special solemnity in the sound of the music.

The 2nd musical theme also contains the anabasis sequence, however its semantic center is the figure $a^{1}-h^{1}-f_{i s}{ }^{1}-a^{1}$, in which (see the notes marked with "circles" in the example) the motives of the Cross and the "ring-circle" are combined, that is, the symbols of the Divine authorities, which in a different texture and interval alignment are approved in the last musical measures of the composition. Thus, the image of theme 2 is a semantic and amplifying quality of expression, but not the antithesis of theme 1 . The tonal difference $\mathrm{H}-$ F creates the illusion of a tonal opposition of the type main - secondary, since in essence the variability of their relationship corresponds more likely to the principle of a single-tone suite.

Suite's style is also found in the ratio of Andante sostenuto and the motor skills of the subsequent Allegro - Allegretto scherzando - Allegro moderato, indicative of the French suite (the characteristic slow part of the sonata-poem cycle is absent here), which was specially developed in DebussyRavel cycles at the beginning of the 20th century. As a result, the Glazunov Concerto captures to the greatest extent the aspect of the etymology that captures the genre affiliation of a word and concept, which is consistent with the symphony, and which opposes the later "competitive" dialogical understanding of genre specificity.

The glorious principle of musical expression in composition creates in the figurative setting something very significant for today's stylistic priorities: the minimalist "emancipation of consonance"28, which eliminated the aggressiveness-conflict of the art of the twentieth century for the sake of joy and significance of the approval of archetypal figurative meanings, as well as the revival of the conflict-free art of past centuries.

The indicated thematic constructions of the Concerto, which put forward the generalization of the symbolism of anabasis, the contour of the Cross and the Circle-Ring, moreover, in their non-individualized typical manifestations, bring it closer to the archetypal dimensions of minimalist art of the beginning of the 21st century. Variant repeatability, subordinated to an increase in the intensity of the manifestation of the once declared quality, but not development as an exit to a qualitatively new meaning, is the specific structure of the image, which makes this composition related to preminimalism, and in fact, minimalist compositions. The timbral promotion of the single image of the State from a modest "singing" manifestation of male voices at the beginning of the composition to the luxury of a bell-shaped

${ }^{28}$ Androsova D. (2008). Minimalism in music. Scool appliances for universities of arts. Odesa: Astroprint. P. 26. 
multi-oversized "chime" of the final passages, is the dramatic logic of monologism, in which the complementarity-compensator of the orchestra and soloist plays a leading role in creating a sound ensemble.

Contemporary performance, with an eye to the discovery of "rehearsal" technique as the basis of pianism in piano sound production ${ }^{29}$, is enthusiastically turning to the "conflict-free dramaturgy" of classic-romantic works of the era of the triumph of symbolism. We add to the experience of the art of the East, cultivating aesthetic values, contrary to the artistic expressiveness of the music of "emancipated dissonance" of the XIX XX centuries. The fluidity of playing music such as the Second Piano Concerto A. Glazunov corresponds to the ecstatic attitudes of musical creativity at the beginning of the third millennium.

The pianist avoids contrasting performances where they are prompted by a composer text, softening even those "smoothed", in comparison with romantic poem, contrasts that are outlined by the author.

Thus, the written "brilliant" sound at the beginning of the Concerto, in a high tessitura and, the lightly declared main theme of the work in the tonality of romantic enthusiasm Fis-dur (from vol. 5 after p. 2) is called, once according to Glazunov's text, "light up "on forte. But the performance of Alekseev is clearly mezzo forte, no more.

In the same way, the pianist solves the "rapprochement" of tempodynamic contrast constructions in the following places. These are the "roll calls" (note, not the piano and the orchestra, but the phrases-motifs in the piano part itself from c. 16) fortissimo and subito piano, - Alekseev absolutely does not complement F. Liszt's style, but does not oppose these layers of sound. The pianist sensitively "picks up" that subtle rhythmic play that the composer "proposed" in his composition, laying the anthem as the main theme.

An elementary calculation of the durations in the title topic, carried out in the first bars, shows a five-part size (in the example, the dashed line indicates the breakdowns of five quarter). The same topic in the re-conducting in E-dur (c. 55) sounds $4 / 4$, but is recorded in sync (again, the dotted line indicates the real score for the topic itself).

With these tricks, Glazunov, in the Russian vocal tradition of "veiling" clock ticks, points to a special smoothness, "flowing" of sound, to "phrasal breathing" as the basis of rhythmic sensations. The pianist, D. Alekseev, interprets this tendency in his own way - introducing the rhythm of the "Russian waltz" (that is, with the most weakened rhythmic pulsation by $3 / 4$ ) into the sound - from the beginning to the end of the work.

${ }^{29}$ Stepanova O.Yu. (2018) Pianism Londonskoyi i Wiedenskoyi fortepiannyh zhkil: komparattyvnyj analiz. Kandydat.dysertacja, 17.00.03 SDPU mneni A.Makarenka, Sumy. 
This is how the "generalizing" (in the terminology of V. Medushevsky) looms up intonations of performance, communicating a single rhythm-timbre tone of the entire length of the concerto-poem sound. This vividly erupts in the sound of a unifying final phrase of a work in which the general «ritenuto» is read with a "waltz breakdown" of quarter-length even spells (in the example, the author's version is compared on the left and the reality of the rhythmic presentation by the pianist is on the right).

The named waltz style in Alekseev's presentation is justified by the association with the image of Glazunov, the author of "Chopeniana," moreover, in the ballet music it was the waltz fragments that became compositionally decisive. This is the ability to hear the Polish genius given by the Russian composer: for Schumann, the appearance of Chopin was associated with the style of a nocturne - see the play "Chopin" in "The Carnival", for Rachmaninov - with Prelude No. 20 c-mall, but for Schoenberg - "Chopin Waltz", No. 6 in "Lunar Pierrot".

So, D. Alekseev defined the line of waltz movements as "through" in the sound of the Concerto Glazunov, intonationally updating the principle of a "spiritual concerto" or concerto da chiesa, an "obligate" concert opposing a "concert-competition" of the period after Beethoven and Liszt. We note that the features of this second type are present in the form of a "game of dynamics" in Glazunov's work - and it is possible to "unfold" this principle within the limits set by the concept of the work. This partial "theatricalization" of sound does not contradict the principles of theatricality and ballet attitudes of the author of "Raymonda" and "Chopeniana" and the programmatic background of the analyzed work. Especially in the context of the historical fate of the dedication to the emperor, who became the martyr of the Revolution, as if "pushes" to the dramatization of dialogical premises of the text of Glazunov.

We emphasize the presence of pre-minimalist qualities of style in the work of A. Glazunov, which is based on the unfolding of a lyrical glorifying monologue based on archetypal landmarks of the product's images (symbols of the Ascension, Cross-Circle as the beginning and end point of sound). Hence the performing advantage, from the perspective of the postmodern of today, the unfolding of the image, the latter's focus on the aesthetics of chanting and the antithetic dialogic nature of the romantic concerto.

A. Glazunov's lyrical gift is extremely attractive for Chinese musicians from the perspective of his creative appearance, since artistic aesthetics forms an organic component of the tradition of Chinese art. The performance of Glazunov's works in China, we believe, is the number one perspective for the cultural interaction it is known that A. Glazunov repeatedly came to Ukraine, in particular to Odessa. Here, in Ukraine, contact was made with the Polish 
composer K. Shimanovsky. In Odessa the Glazunov name was received by the Children's Music School No. 2 for the composer's active support for the activities of Odessa musicians.

\section{CONCLUSIONS}

An analysis of A. Glazunov's creative positions in relation to the piano genres and compositions of Concertos for piano and orchestra No. 1 and 2, allows us to draw a number of conclusions that somewhat complement the ideas about the contribution of this author to world culture.

Firstly, we specifically note the "Mozart's complex" by A. Glazunov both along the lines of extremely early detection of the composer's gift ("composer prodigy" as Dr. D. Goiovi put it), solidarity with his youthful compositions by the composers of the "Mighty Handful" of the 1880s, and the general tone of harmony in the artistic manifestation of the figurative attitudes of his works.

Fourthly, the symbolist era of the formation of Glazunov's work determined the richness of symbolism in his compositions, including the considered Piano concertos. Direct and stylistic quotes, and tonal symbolism create interesting allegorical figures in his works, in particular, this is the exclusivity for Glazunov to appeal to the keys $\mathrm{f}$ and $\mathrm{h} / \mathrm{H}$. The demonstrative completion of the Second Piano Concerto, not in the main key, but in E-dur, indicates the deliberation, the symbolic interpretation of this tonality, which was established in romantic art as the "tonality of an ideal state". The performance decision of the piano concertos was laid down by the pianistic activity of the daughter of A. Glazunov - E. Glazunova-Gunther, who combined F. Liszt's technique with the French principle of the clavier of a lighter type. The pianistic manner of Glazunov himself, possessed of magnificent fluency, but emphasizing the "lightness" of the swan figures with the "playing with a cigar" manner, precluded the concentration of orchestral pianism in the spirit of F. Liszt.

The «reading» of the Second Concerto by Glazunov Alekseev highlighted that sphere of the "Russian waltz style" that organically entered through the work of Tchaikovsky-Prokofiev-Sviridov into the system of Russian music of the twentieth century. The first piano concerto addresses the cultural values of traditional music - in the context of extremists coming to the historical stage from politics and art. The second piano concerto declares Glazunov's social and moral attitudes towards the stabilization of national consciousness in the crucial period of revolutionary transformations in politics and in artistic activity. 


\section{SUMMARY}

The article analizes the piano concertos of A.Glazunov as well as the specifics of the composer's piano style. The creative biography of the composer, who, as a gymnasium student, became the author of a recognized symphonie, work and demonstrated the "Mozart Wunderkind complex", and also discowered the cultivation of Mozart's "light” pianism. So A.Glazunov opposed himself to the representatives of the Russian Five, who were gnded by the orchestral pianism of F.Liszt. This pianistic position was consistent with the composer attitudes towards the "reconciliation" of the of St.Peterburg and Moscow, which was prticulaly defined in the "poem not in the style of F.Liszt" of the two Glazunov Concerto, which noted significant milestones in the life of Russian, Ukraine and a demonstration of profective, state-building thinking systems of Glazunov as a composer and citized.This is evidenced by materials related to the ovesseas period of life and the work of Glazunov, who accomplished mang useful for the musical life of Ukraine and especially Odessa.The general stylistic principles of Glazunow's thinking in his piano work demonsrate a commitment to moderate neockassicism and traditionalism, which were combined in the epic-lyric style of the works of the great composer of the twenticth century.

\section{REFERENCES}

1.Adler G. (1924) Handbuch der Musikgeschichte. Frankfurt a.M.: Verlag-Anstalt [in Germany].

2. Alshvang A. (1967) P.I. Chaikovskiy. Moscow, Muzyka [in Russian].

3. Androsova D. (2008) Minimalism in music. Scool appliances for universities of arts. Odessa, Astroprint [in Ukrainian].

3. Androsova D. (2014) Symbolism and polyklavier type in piano performance art XX century. Monograph. Odesa: Astroprint [in Ukrainian].

4. Ganina M. (1961) A.K. Glazunow. Life and creative activity. Leningrad [in Russian].

5. Glazunov. The studies.The materials.The publications.Letter. V. 1-2. Moskva, Muzyka. T. 1. P. 104-105 [in Russian].

6. Glebov I. (B.Asafiev). (1924). A.Glazunov. Experience of analysis. Leningrad [in Russian].

7. Gojowy D. (1986). Alexander Glasunow. Sein Leben in Bildern und Dokumenten. Unter Einbezihung des biographischen Fragments von Glasunows Schwierigersohn Herbert Günter. München: Paul List Verlag GmbH \& Co.KG. [in Germany].

8. Kryukov A. (1966) Alexandr Konstantinovich Glazunow. Moskva: Muzika. [in Russian]. 
9. Liu Bing Jang (2014). Music-history parallels of the development of the art to China and Europe. Monograph on histories of the culture for music academy, university and high school art. Odessa: Astroprint [in Ukrainian].

10. Markova E. (1990) The intonation character of music art. Kiev: Muzychna Ykrajina [in Ukrainian].

11. Markova E. (1968) The preludes and fugues of Glazunov for clavier. Degree work. The library of ONMA name A.V. Nezhdanova. Odessa [in Ukrainian].

12. Markova E. (2012) The problem of music culturology. Odessa: Astroprint [in Ukrainian].

13. Navoeva I.Л. (2018) Ukrainian choral, vocal-ensemble creative activity in context style Neo-Gothic of post-postmodern. Candidate's. Odessa National Musical Academy name A.V. Nezhdanova, 17.00.03 [in Ukrainian].

14. Ossovskiy A.(1907) His(its) life and creative activity / S.-Peterburg [in Russian].

15. Stepanova O.Yu. (2018) Pianism of London and Wien schools: comparative analysis Candidate's. Sumy [in Ukrainian].

Information about the author: Androsova D. V., orcid.org/0000-0002-5951-8416

Professor, hab. Doctor of Arts, Reader of Chair of Theoretic and Applied Culturology in Odessa National A. V. Nezhdanova Music Academy 63, Novoselskoho str., 65024, Odessa, Ukraine 